\title{
INTRODUCTION OF INNOVATIVE PEDAGOGICAL TECHNOLOGIES IN THE PROCESS OF PROFESSIONAL TRAINING OF FUTURE SPECIALISTS PHYSICAL THERAPY, ERGOTHERAPY PROFESSIONALS
}

\section{Kopochynska Yu. V.}

\section{INTRODUCTION}

the content of the subject. In the structure of learning and its development, P. Sikorsky ${ }^{1}$ found a pattern: if students are provided with a considerable amount of information for assimilation, then the opposite effect occurs - a decrease in developmental learning opportunities. This usually leads to a decline in the intellectual development of the learning subjects. In research on the choice of pedagogical technologies that provide for the formation of professional identity, we have taken into account the works of P. Sikorsky and A. Kucherenko. So, according to P. Sikorsky, teaching is such a purposeful pedagogical interaction of teachers and students, which provides education, development and selfdevelopment of subjects of learning, assimilation of the necessary knowledge, skills and knowledge, methods of knowledge of the world around them

The article by A. Kucherenko states that the organization and management of professional training of specialists are based on a certain basis, which contains the following components ${ }^{2}$ :

- Bank of pedagogical technologies, information base of their concepts, algorithms, educational and methodological support;

- criteria for the choice of pedagogical technology, initial positions of designing new educational practice;

- mechanisms of inclusion (development, assimilation, use, introduction of innovative pedagogical technology in the real educational process).

The purpose of the article is to study innovative pedagogical technologies and study the level of their introduction into the process of professional training of future specialists in physical therapy, ergotherapy.

The research used the analysis of scientific literature, synthesis, synthesis and comparison, questionnaire of teachers of higher education institutions of Ukraine.

1 Сікорський П.І. Теорія і методика диференційованого навчання. Львів : СПОЛОМ, 2000. $421 \mathrm{c.}$

${ }^{2}$ Кучеренко А.А. Сучасні вимоги до військово-професійної підготовленості офіцерів-прикордонників. 3б. наук. пр. Хмельницький: Наи. академія ДПСУ, 2004. № 26. Частина II. С. 138-139. 


\section{General characteristics of innovative pedagogical technologies}

In the introduction of new educational technologies into the educational process, we relied on the laws of personality development, since the principle of high-level learning requires technology that enables the organization of training with each group in the area of greatest development, separating the core of knowledge for assimilation and their specific set for fulfillment of developmental functions, creation of intellectual field for assimilation of certain educational material ${ }^{3}$.

To effectively implement any learning technology, you need to find out what constitutes the subject.

In the course of the research we have determined that for each discipline there is a model, the basis of which is the general didactic:

1) taking into account in the process of selecting the content of education the need for formation of the subject of learning of human values;

2) anticipation of the opportunity to familiarize the subject with the diversity of values that exist in the world;

3 ) creation of conditions in the content of education for evaluation of values, enabling the learning subject to be guided by them in life and their actions.

Our research has shown that the use of modular programs contributes to the effectiveness of each innovative technology. That is why we have paid considerable attention to modular technology, which is versatile and can be constantly refined, which has been used in the process of professional identity formation.

Innovative pedagogical activity is associated with the change of traditional stamps, stereotypes in teaching, so the education and development of the student go beyond the usual actions. The provision of innovative activity is based on socio-cultural, moral and spiritual factors ${ }^{4}$.

As we research and design pedagogical systems, the key feature of which is innovation, we take the connection of design with innovation as a fact and a starting condition, and consider the concept of "pedagogical technology" as a systematic and consistent implementation by the teacher in the practice of projected pedagogical orientation professional tasks ${ }^{5}$.

3 Романишина О.Я. Компоненти, критерії та показники сформованості професійної ідентичності в майбутніх учителів нематематичних спеціальностей. Молодий вчений. 2015. № 8 (23). Ч. 1. С. 134-138.

${ }^{4}$ Смирнов С.Д. Педагогика и психология высшего образования: от деятельности к личности. Москва : Аспект Пресс, 1995. 271 с.

5 Докучаєва В.В. Моделювання інноваційних педагогічних систем. Вісник Луганського держ. пед. ун-ту ім. Т. Шевченка. 2001. № 9 (41). С. 51-57. 
Let us dwell on the characteristics of innovative technologies that contribute to the formation of professional identity of future specialists in physical therapy, ergotherapy.

Modular learning technologies. Given that modular technology is the basis for others, the effectiveness of other technologies depends on the correctness of its organization. The basis of modular technology is the principle of autonomous content units - "microcourses", which can be freely combined within one or more training programs. Determining the content of a share of educational material depended on the specific didactic tasks that the teacher set himself.

Currently, specific learning technologies need to be directed at the student's personality, so their development involves following a certain sequence:

- determination of the final product of the activity;

- selection of part of the final product of activity;

- outlining the main actions, means, methods of achievement, as well as the educational material necessary for the formation of a certain skill;

- determination of methods of control over the implementation of the developed skills and competences;

- creation of a correction system, correction of the performed actions ${ }^{6}$.

Modular technology is implemented in the following stages:

And - acquaintance with the basics of module training;

II - creation of modular version of the program;

III - definition of basic methods, forms and means of training;

IV - determination of control methods and forms;

$\mathrm{V}$ - provision of appropriate teaching materials;

VI - development of technological map of the student and the teacher.

These steps were used in the development of work programs of the disciplines.

We have considered several types of modular technologies, among which the goals of our research are: modular-developmental, modular-credit, credit-transfer, modular-rating. The most important for the formation of professional identity are module-rating, module-credit and credit-transfer technologies, which are entirely based on modular technology. Among others, we used information education technology, research, design, and interactive technologies.

We briefly characterize these technologies as their influence on the formation of professional identity is significant.

6 Гальперин П.Я. Психолого-педагогические проблемы программированного обучения на современном этапе Москва, 1966. 39 с. 
The technology of module-rating training is based on the mobility of the modular construction of the content of education, creative independent cognitive activity of teachers and students, updated and enriched rating control of knowledge, cooperation of all participants of the educational process. Activity, independence, mobility, competitiveness, creativity and initiative, striving for self-fulfillment - perspective qualities of the student, which are formed during the module-rating training ${ }^{7}$. The module is considered as a logically complete part of theoretical knowledge and practical skills in a particular discipline, and the rating - as a student position in the group on the results of training in a certain subject, determined by the rating (percentage of the sum of the supporting grades of all possible modules to the sum of maximum modules) ${ }^{8,9}$.

Within the subject, each module is related to the previous and the next in content. Their material is divided into structural parts - training elements, for which they specify the purpose of the study and provide the necessary methodological recommendations. Each learning element is an autonomous part of the learning process. Assimilation of the module begins with an introductory overview lecture of general content, which sets the benchmarks of the subject course they are studying. Further activities of students are consultations, individual work, tutorials, which can be considered as seminars, practical and laboratory work. Practical classes use various forms of learning activities: group and team work, discussions, debates, miniconferences, project work, problem solving, role and business games, etc. All this is the content of a separate module. Each module of the corresponding training course provides a certain amount of knowledge, skills and skills that a student must master, a list of theoretical and practical tasks that he must complete. The student chooses the variant of the offered tasks available to him according to his abilities. He should know the requirements for the content of each training element at a specific level. Performing highlevel tasks, the student develops additional literature, writes creative work, abstracts, summaries, reflections, develops devices, etc. By agreement with the teacher, the contents of the module can be delivered more quickly by the student, using his spare time to meet other learning interests. Each module

\footnotetext{
${ }^{7}$ Копочинська Ю.В. Формування професійної компетентності студентів як засіб залучення до наукової та інноваційної діяльності. Znanstvena misel journal The journal is registered and published in Slovenia. 2017. № 10. С. 63-64.

${ }^{8}$ Коломієць А.М. Використання інформаційно-телекомунікаційних технологій у підготовці майбутніх педагогів. Інформаційно-телекомунікаційні технології 6 сучасній освіті: досвід, проблеми, перспективи: зб. наук. пр. Львів : ЛДУ БЖД, 2006. C. $550-555$.

${ }^{9}$ Шевченко Н. Ф. Становлення професійної свідомості практичних психологів у процесі фахової підготовки : монографія. Київ : Міленіум, 2005. 298 с.
} 
provides several types of control: testing, seminar, training, colloquium, abstract, etc. The results of each type of control express a certain number of points, depending on the importance of the training material and the characteristics of the type of control. Module rating consists of the sum of indicators of success for the types of control provided by this module: introductory, current, final and deferred ${ }^{10}$. After studying a certain module, the rating is output in points for each student.

Module-rating technology provides for the consistent assimilation of educational material into integral, logically ordered and substantiated parts (modules), and the results of the knowledge test are the basis for determining the student's rating among classmates.

The introduction of this technology significantly influenced the formation of professional identity of future teachers: it prompted students to acquire knowledge independently, to use the teacher's methodological advice, but it also took into account the students' individual abilities, their temperament, the formation of their professional interests, and the formation of their own "Self". However, technology requires considerable time to develop, validate module tasks, level of knowledge, skills and skills of students ${ }^{11}$.

Modular rating technology has helped to shape the professional identity of future specialists in physical rehabilitation, as consistent learning of the material in holistic, logically ordered and substantiated parts (modules) promotes the development of the cognitive component, develops skills and skills.

The credit-module system of organization of the educational process of training specialists opens new opportunities in the higher education system. Its implementation was facilitated by the following factors: motivation of learning, need for training, volume of educational activity, regularity and systematic learning, activity of students in learning, application of knowledge in practice, type and character of educational activity, level of students' readiness, periodicity of control and testing of knowledge, volume and peculiarities of self-study, forms of teaching material, type and structure of teaching, psychological conditions of learning, teaching aids, style of relations between teacher and student, etc.

The purpose of the credit-module system is:

- Achieving compliance with the standards of the European education system based on the skills and competences acquired by the graduate;

${ }^{10}$ Булах I.С. Теорія і методика комп'ютерного тестування успішності навчання (на матеріалах медичних навчальних закладів) : дис.... д-ра пед. Наук : 13.00.01; Київ, 1995. 430 с.

Исаев И.Ф. Развитие профессионально-педагогической культуры преподавателя в условиях модернизации педагогического образования. Педагогіка та психологія: зб. наук. пр. Харків, 2006. Вип. 29. С. 63-72. 
- the demand for Ukrainian educational qualifications in the European labor market;

- approval of the common and comparative system of educational qualification degrees;

- introduction of a standardized diploma supplement, model of which is developed in accordance with the European system, contains detailed information on the results of graduate studies;

- encouraging teachers and students of higher education institutions to improve the system of objective assessment of the quality of knowledge;

- ensuring the transparency of the higher education system and academic professional recognition of qualifications (diplomas, degrees, certificates, etc.).

For the introduction of such technology, in addition to the generally accepted, the following specific principles were used: comparison of the complexity of credits (consists in achieving each student established ECTS norms that ensure academic mobility of students, national and international determination of research results); credit (consists in decomposing the content of education and training into relatively separate parts); modularity (defines the approach to the organization of mastery of students semantic modules and is manifested by the specifics of module learning); methodological consultation; organizational dynamism ${ }^{12}$.

Credit-modular technology of the organization of educational process combines modular technology of teaching and credit educational units, socalled credit credits. The use of credit and module technology implies the following principles:

1) the comparative complexity of credits - is to achieve each student established ECTS norms that provide him with academic mobility, national and international recognition of educational outcomes at specific stages of implementation of the individual curriculum;

2) subject matter - provides for the decomposition of the content of education and training into a single and relatively independent share of students, which provide:

a) at the level of the individual curriculum - a set (accumulation) of a given complexity of the number of credits that correspond to the calculated norm of the student's performance of the academic load in the conditions of the credit-module organization of the educational process;

b) at the level of study of a discipline - a set (accumulation) of a certain amount of credits for a certain discipline, which provide for the fulfillment of the required activities under the program of study of the discipline;

12 Алексюк А.М. Експериментальне впровадження технології модульної організації навчання у вищій школі. Проблеми вищої школи. 1994. Вип. 79. С. 3-6. 
3) modularity - defines the approach to the organization of mastery of the student content modules and is revealed through the organization of methods and techniques of educational and educational activities specific for module training, the main content of which is the active independent creative cognitive activity of the student;

4) methodological consulting - consists in scientific and informational support of the activities of the participants of the educational project;

5) organizational dynamism - involves providing the opportunity to change the content of training taking into account the dynamics of social order and labor market needs;

6) Flexibility and partnership - is to build a system of education, according to which the content of training and ways to achieve the goals of vocational training will meet the individual opportunities and needs of the student;

7) Priority of content and organizational independence and feedback involves the creation of conditions for the organization of learning, which can be measured and evaluated by the results of students' independent cognitive activity;

8) scientific and predictive - it is to build (establish) strong links between the content of education and research;

9) adaptability and innovation - involves the use of effective pedagogical and information technologies that contribute to the qualitative training of specialists with higher education and entry into a single information and educational space;

10) Conscious Perspective - is to provide the student with a deep understanding of the goals of education and training, as well as the possibility of their successful achievement;

11) Diagnostics - contributes to ensuring an objective assessment of the level of achievement and effectiveness of the goals of education and training ${ }^{13}$.

Credit-transfer system of organization of educational process is a model of organization of educational process, which is based on the combination of modular technologies of teaching and credit educational units (credit credits).

Important tasks of training specialists in terms of credit transfer technology training is to provide a quality degree education, targeting the personality of the future specialist, creating conditions for updating the content and forms of organization of the educational process, the introduction of educational innovations and information technologies, the formation of systemic pedagogical education.

${ }^{13}$ Пєхота О.М., Кіктенко А.З., Любарська О.М. Освітні технології: навч.-метод. посіб. Київ : А.С.К., 2001. 256 с. 
For the implementation of credit transfer technology, the general didactic requirements (consistency and systematic learning, consciousness, independence and activity in learning, individualization and differentiation, professional orientation, scientific, optimization, emotionality, communication of theory with practice) and specific principles (principles) should be observed, systematic, technological and innovative, diagnostics, priority of content and organizational independence, subjectivity of the educational process, personal about purposefulness, emotional and value orientation of the educational process, adequacy of forms of interaction of the subjects of learning with the levels of assimilation of the substantive content of activity and levels of self-regulation of its functional components, meaningful continuity in the organization of activity). Technology envisages improvement of curricula, programs, manuals, intensification of the educational process, content, methods and means of training, ensuring communication between all subjects of the cycle, development of educational and methodological complexes, rational distribution of the content of educational material on the module and checking the quality of assimilation and practical material of each module, use of a wide flexible scale of knowledge assessment, provides real differentiation of students' knowledge, stimulation of their active self-work during the whole period of study at the ZVO, increase the objectivity of knowledge assessment, the introduction of healthy competition in learning, the identification and development of students' creative abilities.

In the conditions of credit transfer technology, the function of the teacher in the organization of students' educational activity changes. Its main task is to manage the students' independent work, to form the motivating learning motives, to define the goals and objectives of the educational activity, its organization, to control the results of the learning process. Credit-transfer technology involves a new requirement for the teacher - a combination of consultant and manager functions to use the information-educational environment, to be able to teach teaching material so as to ensure effective independent work of students, to actively use the communicative capabilities of computer programs and networks to organize effective educational and cognitive activity, constantly monitor the learning outcomes. The educational process is conducted on a parity basis.

Problem-oriented learning - a method of organizing the educational process, aimed at independently active solution of the problem situation, set by the teacher, resulting in a creative mastery of professional knowledge, skills and skills and the development of intellectually creative and mental abilities. It is the setting of a problem or problematic task that is close to the life situation that allows students to quickly and easily engage in a real professional position. Self-correction leads to the formation of 
self-organization, self-study and self-control skills, thus increasing the responsibility of the future specialist in physical therapy and ergotherapy. The very methodology of problem-oriented learning contributes to the development of a conscious, motivational approach to learning.

Problem education, first of all, is aimed at activating the cognitive activity of students, forming logical thinking, developing the creative qualities of each student with the help of a teacher's problem. The purpose of problem training - in search; development of students' mental activity. The advantage of problem-based learning lies in a clear statement of the problem to which the student must give a clear answer with a clear formulation and proof of their answer, consolidation of previously acquired knowledge and skills, collaboration of students in a group, forming the ability to collectively solve a problem, which, in turn, is necessary a condition of work of a specialist in physical therapy and ergotherapy in a multidisciplinary team. This approach to solving the problem forces students to independently search for solutions, to find missing knowledge, using previously acquired at the adjacent departments, which requires them mental activity, conclusions.

Team-oriented learning is a method of teaching based on small groups of 3 to 4 students of different levels of preparation, with the composition of the groups being constant. The main purpose of the team-oriented teaching method is to teach students to work in a team, to assist in understanding and learning new knowledge; every student should feel the support of a team that will give him / her a belief in oneself, a desire for self-improvement. Teamoriented training focuses on the development of teamwork skills, the formation of communication skills, the experience of working in a multidisciplinary team. This technology guides students to understand the purpose of the course, the application of theoretical knowledge obtained during lectures, seminars and during practice. Teamwork helps in understanding and mastering difficult issues, facilitates mutual cooperation in solving problems.

Clinical case studies are conducted using situational tasks, business roleplaying in a team. This approach allows you to share roles and responsibilities between students. Teamwork helps students to jointly solve a difficult task, helping each other, make and respect the decisions of a team member, learns to defend their point of view, promotes communication skills, nurturing teamwork. One of the conditions for working in a team is the right selection of students. The composition of each team is selected in such a way that it has students with different levels of knowledge, both strong and weaker students. Only by following this rule can we achieve the result - the development of communication skills, the ability to provide assistance and support in a difficult situation. 
Project-oriented learning is research technology. This method is based on the active participation of students in scientific projects and aims at the development of research, problem, search, creative competencies. The design methodology most easily fits into the learning process and may not affect the content of the training, which is defined by the educational standard for the basic level; allows to integrate it into the real educational process more successfully to achieve the goal set by the state standard of education; provides not only a solid learning material, but also the intellectual and moral development of students, their independence, kindness towards the teacher and each other, communication skills, a desire to help others. The purpose of project training is to form students' creative thinking, independent work skills; ability to use acquired knowledge; development of research skills; formation of communication skills, group work skills, teamwork ${ }^{14}$.

Information Educational Technology. Among modern educational technologies in higher education institutions all over the world occupy a special place information, the necessity of which introduction into the educational process is undeniable. Information technology is one of the most important means of raising the intellectual level of a person, in particular qualitative improvement of training of future specialists, who should possess such skills:

- use information retrieval and information systems to find and effectively use educational, developmental information;

- use multimedia encyclopedias, electronic dictionaries, translators and simulators for intensive multimedia training;

- use information and communication technologies to prepare, support, analyze and adjust the educational process;

- apply individual and differentiated approaches to training based on information and communication technologies ${ }^{15}$.

The main tasks of educational information technologies of education are: intensification of all levels of educational process, improvement of its efficiency and quality, systematic integration of knowledge industries, development of students' creative potential, their ability to communicate, the formation of information culture, the development of experimental research and culture activities, realization of social order, conditioned by informatization of modern society - providing future specialists with skills

14 Дмітрієва Н.С., Копочинська Ю.В. Сучасні педагогічні технології у професійній підготовці фахівців 3 фізичної терапії та ерготерапії. Вісник Прикарпатського університету. Серія: Фізична культура. 2019. № 32. С. 64-70. DOI 10.15330/fcult.32.64-70

15 Гуревич Р.С., Кадемія М.Ю., Козяр М.М. Інформаційно-комунікаційні технології в професійній освіті. Львів, 2012. 506 с. 
and skills meadow Computer Science, training of users of new information technologies.

Nowadays, the organization of the educational process requires the combination of different technologies, creative approach to their use, as well as the creation of new educational technologies. The teacher's ability to apply different learning technologies enables him to creatively organize the students' educational and cognitive activities, to choose under specific conditions the technology of learning that best ensures the acquisition of knowledge, the formation of skills and skills with minimal effort and time.

The technologies selected for the study are combined by common characteristics that form the basis for the formation of professional identity and professional skills:

1. Possibility to identify and introduce new scientific-methodological and pedagogical approaches to the planning and organization of the educational process.

2. Creation of modern diagnostic and monitoring tools for evaluating the activities of students and teachers of higher education.

3. Placement of materials from each discipline of the curriculum and methodological materials on the sites of institutions of higher education.

4. Creating a unified information environment with unified terminology, conceptual apparatus for communication on the quality of training.

5. Development of modular programs, in which mini-modules could be easily replaced, renewed, transformed, adapted.

6. Provision of the educational process with an appropriate number of special courses that will allow the student to make his / her own choice of credits.

7. Substantiation of approaches to decomposition of educational disciplines and technologies of their teaching in the conditions of creditmodular system.

\section{State of introduction of innovative pedagogical technologies process of professional training of future specialists in physical therapy, ergotherapy in Ukraine}

In order to determine the level of introduction of innovative pedagogical technologies in the process of professional training of future specialists in physical therapy, ergotherapy was conducted a survey of teachers of 6 institutions of higher education of Ukraine, which provide training for specialists in this field. The survey was attended by teachers of higher education institutions such as Academician Yuriy Bugay International Scientific and Technical University, Poltava Institute of Business Academician Yuriy Bugay International Scientific and Technical University, National Technical University of Ukraine "I. Sikorsky Kyiv Polytechnic Institute", 
National Pedagogical Dragomanov University, Lviv State University of Physical Culture and Classic Private University.

For our research, it is important to determine whether modern scientific and methodological literature is needed in the institutions of higher education of Ukraine, necessary for the formation of professional identity of future specialists in physical therapy and ergotherapy. According to the results of the survey it was found that $26.29 \%$ of the respondents believe that the scientific and methodological literature is available in sufficient quantity, $52.97 \%$ indicated its insufficient amount, $20.74 \%$ said that it was not in the public domain.

The results of the survey show that $26.67 \%$ of teachers attribute the lack of awareness about the possibilities of applying the best world experience, $26.78 \%$ - the irrational organization of the process, to the barriers of formation of professional identity of future specialists in physical therapy and ergotherapy in the process of professional training, $7 \%$ - insufficient logistical support, $23,42 \%$ - lack of necessary educational and methodological and information base, $14,33 \%$ said that they were difficult to answer.

The level of introduction of the newest computerized systems in the process of professional training of future specialists in physical therapy and ergotherapy is estimated by $68.88 \%$ as sufficient, $22.27 \%$ and $8.85 \%$ of respondents chose the answer "hard to answer".

Because the study identified team-based training as effective for occupational identity formation, teachers were asked "Do you encourage future practitioners in physical therapy and ergotherapy to join separate groups to solve practical problems?". The analysis of the answers showed that $61.52 \%$ of the teachers encourage students to work as a team, $25.26 \%-$ partially encourage and $1.42 \%$ difficult to answer.

It is also important to highlight the level of implementation of imitation learning technologies. Thus, $39.39 \%$ of teachers use imitation learning technologies, $22.91 \%$ partially apply and $37.7 \%$ do not apply.

The method of project-oriented training in the professional training of future specialists in physical therapy and ergotherapy is used by $39.19 \%$ of teachers, partially applied by $28.59 \%$, not applied by $27.13 \%$ and difficult to answer by $5.09 \%$ of teachers.

According to the results of the survey, it was determined that $43.55 \%$ of respondents use multimedia training tools, $40.61 \%$ - partially apply, $6.37 \%$ - do not use, $9.47 \%$ of respondents chose the option "yes; to answer".

It was important for our study to determine the level of implementation of a modular object-oriented dynamic Moodle learning environment in the organization of professional training of future specialists in physical therapy and ergotherapy. The results of the survey show that $\%$ of teachers have 
chosen the answer "Yes, I will apply",\% - "Partially apply", 7.40\% "No, I will not apply" and 0\% - "Difficult to answer".

It is established that $41.25 \%$ of teachers use the system Electronic Journal on-line in the organization of professional training of future specialists in physical therapy and ergotherapy, partially apply $37.92 \%$, do not apply 20.83 .

In the organization of professional training of future specialists in physical therapy and ergotherapy, $9.23 \%$ of teachers use interactive computer simulator programs, $32.41 \%$ - partially and $58.36 \%$ do not use it.

An indicator of the level of integration of information educational technologies is also the use of computer-based testing by teachers of higher education to determine the level of knowledge of future specialists in physical therapy and ergotherapy. The survey results show that computer testing is used by $52.88 \%$ of respondents, partly by $40.52 \%$, and not by $6.6 \%$.

The results of the survey allowed us to determine that the method of situational tasks and case-study exercises in the organization of vocational training is used by $47.74 \%$ of respondents, partially applied by $46.42 \%$, does not apply $5.84 \%$. It was also found that the brainstorming method was used by $53.2 \%$ of respondents, partially used by $31.12 \%$, did not apply by $11.03 \%$, and the answer was "difficult to answer" by $4.66 \%$ of teachers.

The results of the research of innovative pedagogical technologies have made it possible to establish that the interprofessional approach to the activity of physical therapists and ergotherapists creates the conditions for the integration of knowledge and skills in different disciplines of health care. To determine the level of implementation of this approach, teachers were asked "Do you use cross-curricular connections in the future training of future specialists in physical therapy and ergotherapy?". The analysis of the answers showed that the crosscurricular approach among the interviewed teachers is used by $30.37 \%$, partially applied by $38.32 \%$ and $31.31 \%$.

\section{CONCLUSIONS}

Thus, the analysis of innovative pedagogical technologies that need to be implemented in the process of vocational training was carried out. These are technologies such as modular training technologies, problem-oriented training, team-oriented training, clinical case-based training, project-oriented training, information educational technologies.

We have identified several types of modular technologies, among which the goals of our research are: modular-developmental, modular-credit, credit-transfer, modular-rating. The most important for the formation of professional identity are module-rating, module-credit and credit-transfer 
technologies, which are entirely based on modular technology. Among others, we used information education technology, research, design, and interactive technologies.

The main tasks of educational information technologies of education are: intensification of all levels of educational process, improvement of its efficiency and quality, systematic integration of knowledge industries, development of students' creative potential, their ability to communicate, the formation of information culture, the development of experimental research and culture activities, realization of social order, conditioned by informatization of modern society - providing future specialists with skills and skills meadow Computer Science, training of users of new information technologies.

The results of the survey conducted by teachers of higher education institutions in Ukraine have made it clear that the organization of the educational process now requires the combination of different technologies, creative approach to their use, as well as the creation of new educational technologies. The teacher's ability to apply different learning technologies enables him to creatively organize the students' educational and cognitive activities, to choose under specific conditions the technology of learning that best ensures the acquisition of knowledge, the formation of skills and skills with minimal effort and time.

It is established that the basis for the formation of professional identity and professional skill are:

1) the ability to identify and implement new scientific, methodological and pedagogical approaches to the planning and organization of the educational process;

2) creation of up-to-date diagnostic and monitoring tools for evaluating the activities of students and teachers of higher education;

3) placing on the websites of institutions of higher education materials from each discipline of the curriculum and methodological materials;

4) creation of a single information environment with unified terminology, conceptual apparatus for communication on the quality of training;

5) development of modular programs in which mini-modules could be easily replaced, renewed, transformed, adapted;

6) providing the educational process with an appropriate number of special courses that will allow the student to make his / her own choice of credits;

7) substantiation of approaches to decomposition of educational disciplines and technologies of their teaching in the conditions of creditmodular system. 


\section{SUMMARY}

The purpose of the article is to study innovative pedagogical technologies and study the level of their introduction into the process of professional training of future specialists in physical therapy, ergotherapy. The research used the analysis of scientific literature, synthesis, synthesis and comparison, questionnaire of teachers of higher education institutions of Ukraine. The technologies of organization of vocational training, such as modular technologies of training, problem-oriented training, commandoriented training, clinical case-based training, project-oriented training, information educational technologies are distinguished and characterized. It is scientifically substantiated that the most important for the formation of professional identity are module-rating, module-credit and credit-transfer technologies, which are entirely based on modular technology. Among others there are information educational technologies, research, design, interactive technologies. It is important that under the conditions of credit transfer technology, the function of the teacher in the organization of students' educational activities changes. Its main task is to manage the students' independent work, to form the motivating learning motives, to define the goals and objectives of the educational activity, its organization, to control the results of the learning process. The results of the survey conducted by teachers of higher education institutions in Ukraine have made it clear that the organization of the educational process now requires the combination of different technologies, creative approach to their use, as well as the creation of new educational technologies.

\section{REFERENCES}

1. Алексюк А.M. Експериментальне впровадження технології модульної організації навчання у вищій школі. Проблеми вищої школи. 1994. Вип. 79. С. 3-6.

2. Булах I.C. Теорія i методика комп'ютерного тестування успішності навчання (на матеріалах медичних навчальних закладів) : дис.... д-ра пед. наук : 13.00.01; Київ, 1995. 430 с.

3. Гальперин П.Я. Психолого-педагогические проблемы программированного обучения на современном этапе Москва, 1966. $39 \mathrm{c}$.

4. Гуревич Р.С., Кадемія М.Ю., Козяр М.М. Інформаційнокомунікаційні технології в професійній освіті. Львів, 2012. 506 с.

5. Дмітрієва Н.С., Копочинська Ю.В. Сучасні педагогічні технології у професійній підготовці фахівців 3 фізичної терапії та ерготерапії. Вісник Прикарпатського університету. Серія: Фізична культура. 2019. № 32. C. 64-70. DOI 10.15330/fcult.32.64-70 
6. Докучаєва В.В. Моделювання інноваційних педагогічних систем. Вісник Луганського держ. пед. ун-ту ім. Т. Шевченка. 2001. № 9 (41). C. 51-57.

7. Исаев И.Ф. Развитие профессионально-педагогической культуры преподавателя в условиях модернизации педагогического образования. Педагогіка та психологія: зб. наук. пр. Харків, 2006. Вип. 29. С. 63-72.

8. Коломієць А.М. Використання інформаційно-телекомунікаційних технологій у підготовці майбутніх педагогів. Інформаиійнотелекомунікаційні технології в сучасній освіті: досвід, проблеми, перспективи: зб. наук. пр. Львів : ЛДУ БЖД, 2006. С. 550-555.

9. Копочинська Ю.В. Формування професійної компетентності студентів як засіб залучення до наукової та інноваційної діяльності. Znanstvena misel journal The journal is registered and published in Slovenia. 2017. № 10. C. 63-64.

10. Кучеренко А.А. Сучасні вимоги до військово-професійної підготовленості офіцерів-прикордонників. Зб. наук. пр. Хмельнииький: Нац. академія ДПСУ. 2004. № 26. Частина II. С. 138-139.

11. Пехота О.М., Кіктенко А.З., Любарська О.М. Освітні технології : навч.-метод. посіб. Київ : А.С.К., 2001. 256 с.

12. Романишина О.Я. Компоненти, критерії та показники сформованості професійної ідентичності в майбутніх учителів нематематичних спеціальностей. Молодий вчений. 2015. № 8 (23). Ч. 1. C. $134-138$.

13. Сікорський П.І. Теорія і методика диференційованого навчання. Львів : СПОЛОМ, 2000. $421 \mathrm{c.}$

14. Смирнов С.Д. Педагогика и психология высшего образования: от деятельности к личности. Москва : Аспект Пресс, 1995. 271 с.

15. Шевченко Н.Ф. Становлення професійної свідомості практичних психологів у процесі фахової підготовки: монографія. Київ : Міленіум, 2005. 298 с.

16. Ясвин В.А. Образовательная среда: от моделирования к проектированию : монография. Москва : Смысл, 2001. 365 с.

Information about the author: Kopochynska Yu. V.,

Candidate of Science in Physical Education and Sports, Associate Professor, Associate Professor at the Department of Biosafety and Human Health National Technical University of Ukraine "Igor Sikorsky Kyiv Polytechnic Institute" 37, Prosp. Peremohy, Solomyanskyi district, Kyiv, Ukraine 